\title{
Aortic stiffness and central hemodynamics in treatment-naïve HIV infection: a cross- sectional study
}

\author{
Pedro Martínez-Ayala', Guillermo Adrián Alanis-Sánchez², Luz Alicia González-Hernández ${ }^{1,3}$, \\ Monserrat Álvarez-Zavala ${ }^{3}$, Rodolfo Ismael Cabrera-Silva ${ }^{3}$, Jaime Federico Andrade-Villanueva ${ }^{1,3}$, \\ Karina Sánchez-Reyes ${ }^{3}$, Moisés Ramos-Solano ${ }^{3}$, Diego Alberto Castañeda-Zaragoza², David Cardona-Müller², \\ Sylvia Totsuka-Sutto ${ }^{2}$, Ernesto Cardona-Muñoz ${ }^{2}$ and Carlos G. Ramos-Becerra ${ }^{2^{*}}$
}

\begin{abstract}
Background: Human immunodeficiency virus (HIV) infection is associated with a greater risk of cardiovascular disease (CVD). HIV infection causes a chronic inflammatory state and increases oxidative stress which can cause endothelial dysfunction and arterial stiffness. Aortic stiffness measured by carotid femoral-pulse wave velocity (cFPWV and central hemodynamics are independent cardiovascular risk factors and have the prognostic ability for CVD. We assessed cfPWV and central hemodynamics in young individuals with recent HIV infection diagnosis and without antiretroviral therapy. We hypothesized that individuals living with HIV would present greater cfPWV and central hemodynamics (central systolic blood pressure and pulse pressure) compared to uninfected controls.

Methods: We recruited 51 treatment-naive individuals living with HIV (HIV $(+))$ without previous CVD and 51 ageand sex-matched controls (HIV negative (-)). We evaluated traditional CVD risk factors including metabolic profile, blood pressure (BP), smoking, HIV viral load, and $\mathrm{CD}^{+}{ }^{+}$T-cells count. Arterial stiffness and central hemodynamics were evaluated by cfPWV, central systolic BP, and central pulse pressure (CPP) via applanation tonometry.

Results: $\mathrm{HIV}(+)$ individuals presented a greater prevalence of smoking, reduced high-density lipoprotein cholesterol, and body mass index. $65.9 \%$ of HIV(+) individuals exhibited lymphocyte CD4 ${ }^{+} \mathrm{T}$-cells count $<500$ cells/mL. There was no difference in brachial or central BP between groups; however, HIV(+) individuals showed significantly lower cPP. We observed a greater cfPWV (mean difference $=0.5 \mathrm{~m} / \mathrm{s} ; p<0.01$ ) in HIV $(+$ ) compared to controls, even after adjusting for heart rate, mean arterial pressure and smoking.
\end{abstract}

Conclusion: In the early stages of infection, non-treated HIV individuals present a greater prevalence of traditional CVD risk factors, arterial stiffness, and normal or in some cases central hemodynamics.

Keywords: Arterial stiffness, HIV infection, Arteriosclerosis, Pulse wave velocity, Cardiovascular risk, Chronic inflammation, Central pulse pressure

\footnotetext{
*Correspondence: carlos.ramos@cucs.udg.mx; md_crb@hotmail.com

${ }^{2}$ Arterial Stiffness Laboratory, Department of Physiology, Universidad de

Guadalajara, Sierra Mojada 950, Building Q, Ground Floor, District

Independencia, 44340 Guadalajara, Jalisco, Mexico

Full list of author information is available at the end of the article
}

(c) The Author(s). 2020 Open Access This article is licensed under a Creative Commons Attribution 4.0 International License, which permits use, sharing, adaptation, distribution and reproduction in any medium or format, as long as you give appropriate credit to the original author(s) and the source, provide a link to the Creative Commons licence, and indicate if changes were made. The images or other third party material in this article are included in the article's Creative Commons licence, unless indicated otherwise in a credit line to the material. If material is not included in the article's Creative Commons licence and your intended use is not permitted by statutory regulation or exceeds the permitted use, you will need to obtain permission directly from the copyright holder. To view a copy of this licence, visit http://creativecommons.org/licenses/by/4.0/ The Creative Commons Public Domain Dedication waiver (http://creativecommons.org/publicdomain/zero/1.0/) applies to the data made available in this article, unless otherwise stated in a credit line to the data. 


\section{Background}

Cardiovascular disease (CVD) is one of the most common causes of death among individuals living with human immunodeficiency virus (HIV), with greater risk for myocardial infarction [1], ischemic stroke [2], and heart failure [3]. Furthermore, an accelerated rate of arterial stiffening has been reported after HIV infection, possibly due to the acute [4] and chronic inflammatory response [5], lipid disorders [6, 7], oxidative stress [8], and the adverse effects of some antiretroviral therapies (ART) [9]. The complex associations between chronic infection, inflammation, and endothelial function have long been studied, but the underlying mechanisms by which HIV infection per se increases the risk for CVD are not completely understood. HIV is capable of penetrating endothelial cells and is able to initiate inflammatory and biochemical intracellular reactions in the coronary arteries [10], the cerebral vasculature [11], and the aortic wall [12]. Moreover, aortic stiffness is associated with coronary artery disease [13, 14]; and it is an independent predictor of coronary events [15]. However, there are contradictory findings on aortic stiffness measured by carotid-femoral pulse wave velocity (cfPWV) in treatment-naïve individuals living with HIV; with some studies showing similar [16, 17] and others increased cfPWV, compared to controls $[18,19]$.

Identification of subclinical changes in the cardiovascular (CV) system, such as arterial stiffness and central hemodynamic assessment, is essential for a more accurate $\mathrm{CV}$ risk classification. Numerous studies have shown that arterial stiffness measured by cfPWV is an independent risk factor for CV events [20] and all-cause mortality [21, 22]. In addition, central hemodynamic assessment via applanation tonometry (central systolic blood pressure $[\mathrm{cSBP}]$ and central pulse pressure $[\mathrm{cPP}])$, better reflect the load imposed on the left ventricle than brachial blood pressure (BP) [23]. The non-invasive central hemodynamic assessment has been reported to have a stronger relationship to organ and vascular damage, as well as to better predict CV events compared to peripheral pressures [24, 25]. Since people living with HIV exhibit a greater prevalence of hypertension [26] and risk of CVD compared to uninfected adults [27], it makes sense to assess central hemodynamics to detect early changes and provide treatment in a timely manner.

It has been reported that ART, specially protease inhibitors (PI), deteriorate arterial function [28]. Unfortunately, a significant amount of available literature looking at cfPWV in HIV combines both individuals on ART and treatment-naïve [29-31]. As a result, the impact of HIV infection per se on arterial function is not clear. For this reason, the objective of this study was to non-invasively assess and compare arterial stiffness and central hemodynamic in non-previously treated (treatment-nä̈ve) individuals living with HIV versus people without HIV.

\section{Material and methods Study population}

Between January 2015 and August 2019, individuals living with HIV were enrolled from the "Antiguo Hospital Civil de Guadalajara" in Guadalajara, Mexico. The study complied with the Declaration of Helsinki and was approved by the ethics committee of the Hospital Civil Fray Antonio Alcalde. Informed consent was obtained from every participant. At study entry, participants' past medical history and demographic information was obtained by a questionnaire. Inclusion criteria for individuals living with HIV included: a) Patients with 18 years of age or older with confirmed HIV infection and no previous ART, b) Absence of current or previous rheumatological or neoplastic disease or CVD; c) Without opportunistic infections at the time of enrolment. Our control group was a group of healthy volunteers who were paired by age and sex. HIV infection was ruled out by a rapid serological test (Architect HIV Ag/ Ab reagent kit, Abbot). In addition, lab tests and medical interrogation were performed to rule out metabolic alterations (e.g. diabetes mellitus or dyslipidaemia) or medical history of cardiovascular disease, in which case were excluded as controls. Inclusion criteria for the control group included: a) Negative HIV serological test, b) No previous cardiovascular or metabolic or rheumatological disease. We aimed to isolate the effect of HIV on arterial stiffness by choosing patients living with HIV without any other comorbidities and comparing them with healthy controls; however, some non-controlled factors were different between the population studied, such as tobacco use and sedentary lifestyle.

\section{Arterial stiffness}

Arterial stiffness was measured by cfPWV as described previously [32] by applanation tonometry (PulsePen, Diatechne, Milan, Italy). cfPWV was calculated as the time delay between the arrival of the pulse wave at the carotid and the femoral artery, divided by the tapemeasured distance between carotid and femoral arteries, minus the carotid-to-sternal notch distance. All measurements were performed by a single trained technician in a temperature-controlled room. The participants rested in a supine position for $15 \mathrm{~min}$ before the assessment and were instructed to abstain from smoking, alcoholic, or caffeinated beverages $24 \mathrm{~h}$ before the evaluation. Two consecutive measurements were performed, and the average cfPWV was used if the difference was lower than $0.5 \mathrm{~m} / \mathrm{s}$. Otherwise, a third measurement was obtained, and the median of the three measurements was used for analysis [33]. cSBP was estimated by 
applanation tonometry on the right carotid artery and calibrated with brachial diastolic blood pressure (pDBP) and mean arterial pressure (MAP) obtained by an automated sphygmomanometer (Omron HEM-907XL). MAP was calculated as $\mathrm{MAP}=\mathrm{pDBP}+$ peripheral pulse pressure (pPP) 0.33. $\mathrm{cPP}$ was determined as $\mathrm{cPP}=\mathrm{cSBP}-\mathrm{pDBP}$.

\section{HIV variables and serum lipids}

A venous blood sample was obtained from the antecubital vein after 8-h fasting. $\mathrm{CD} 4^{+}$T-cells count was performed by flow cytometry (FACScalibur System, Becton Dickinson) and HIV-1 viral load with real-time polymerase chain reaction with retro transcription (Cobas AmpliPrep/Cobas Taqman, Roche Diagnostics). Serum lipids, including total cholesterol (TC), high-density lipoprotein cholesterol (HDL-c), low-density lipoprotein cholesterol (LDL-c), and triglycerides (TG) were determined by colorimetric quantification (AU5800 autoanalyzer, Coulter Beckman, USA). Plasma glucose was determined by photometry (AU5800 autoanalyzer, Coulter Beckman, USA).

\section{Statistical analyses}

Values are presented as mean and standard deviation (SD) or median and interquartile range (IQR), depending on the data distribution. Continuous data were compared using unpaired t-test or Mann-Whitney's test if normally or not normally distributed, respectively. A Chi-square test was used to compared categorical variables. A generalized linear model was used to adjust cfPWV for age, sex, heart rate (HR), MAP, and body mass index (BMI), which affect and could confound PWV values [34]. Statistical analysis was performed using SPSS v.24 (IBM Chicago, IL), and for graphical representation, we used GraphPad Prism version 6.0 (Graph Pad Software, San Diego, California, USA). We calculated the sample size to detect a $0.8 \mathrm{~m} / \mathrm{s}$ difference and standard deviation of $1.01 \mathrm{~m} / \mathrm{s}$, which resulted in 35 individuals in each group, at an alpha of 0.05 and a power of $90 \%$. This calculation was based on the study conducted by Schillaci et al. [18]. The power calculation was performed using GPower 3.1.9.2 [35].. A two-sided $p$-value of $<0.05$ was considered significant.

\section{Results}

We recruited 102 participants; 51 treatment-naïve individuals living with $\mathrm{HIV}(+)$ and $51 \mathrm{HIV}(-)$ participants. $\mathrm{HIV}(+)$ individuals did not show evidence of opportunistic infections on the day of the assessment. Serum lipids

Table 1 Demographic, hemodynamic, metabolic and immune characteristics of the study groups

\begin{tabular}{|c|c|c|c|}
\hline & $\operatorname{HIV}(-)(n=51)$ & $\begin{array}{l}\text { HIV(+) } \\
(n=51)\end{array}$ & $P$ value \\
\hline Age, years & $31.9 \pm 10.2$ & $33.4 \pm 9.9$ & 0.44 \\
\hline Male sex, n (\%) & $45(86)$ & $45(90)$ & 0.56 \\
\hline Weight, kg & $74 \pm 13$ & $66 \pm 10$ & $<0.01$ \\
\hline Cigarette smoking, n (\%) & $12(23.5)$ & $32(62.7)$ & $<0.01$ \\
\hline $\mathrm{BMl}, \mathrm{kg} / \mathrm{m}^{2}$ & $24.8 \pm 3.3$ & $23.2 \pm 4.0$ & 0.04 \\
\hline \multicolumn{4}{|l|}{ Hemodynamic } \\
\hline pSBP, mmHg & $117.8 \pm 10.3$ & $115.1 \pm 12.9$ & 0.24 \\
\hline $\mathrm{pDBP}, \mathrm{mmHg}$ & $64.5 \pm 8.7$ & $65.4 \pm 8.8$ & 0.59 \\
\hline MAP, mmHg & $82.7 \pm 8.3$ & $82.3 \pm 8.8$ & 0.82 \\
\hline $\mathrm{HR}, \mathrm{bpm}$ & $65.7 \pm 11.9$ & $71.2 \pm 13.7$ & 0.03 \\
\hline $\mathrm{pPP}, \mathrm{mmHg}$ & $53.2 \pm 9.4$ & $49.6 \pm 9.2$ & 0.05 \\
\hline \multicolumn{4}{|l|}{ Metabolic profile } \\
\hline $\mathrm{TC}, \mathrm{mmol} / \mathrm{L}$ & 4.1 (3.5 to 4.7 ) & 3.7 (3.1 to 4.4$)$ & 0.05 \\
\hline $\mathrm{LDL}-\mathrm{c}, \mathrm{mmol} / \mathrm{L}$ & 2.5 (1.9 to 2.9$)$ & 2.2 (1.8 to 2.7 ) & 0.29 \\
\hline $\mathrm{HDL}-\mathrm{c}, \mathrm{mmol} / \mathrm{L}$ & 1.1 (1.0 to 1.3$)$ & 0.8 (0.7 to 0.9) & $<0.01$ \\
\hline $\mathrm{TG}, \mathrm{mmol} / \mathrm{L}$ & $1.2(0.9$ to 1.6$)$ & 1.4 (0.9 to 2.1) & 0.25 \\
\hline Glucose, mmol/L & $5.0(4.7$ to 5.3$)$ & 4.7 (4.4 to 5.2$)$ & 0.04 \\
\hline \multicolumn{4}{|l|}{ Immune profile } \\
\hline $\mathrm{CD}^{+} \mathrm{T}$, cells/ $\mu \mathrm{L}$ & - & $496 \pm 298$ & \\
\hline Viral load, copies/mL & - & $70,250\left(1173\right.$ to $\left.2^{\prime} 279,000\right)$ & \\
\hline
\end{tabular}

Values are mean \pm SD and median (IQR)

$B M I$ body mass index, $P S B P$ peripheral systolic blood pressure, $P D B P$ peripheral diastolic blood pressure, $M A P$ mean arterial pressure, $H R$ heart rate, $p P P$ peripheral pulse pressure, $T C$ total cholesterol, $L D L$-c low-density lipoprotein cholesterol, $H D L$-c high-density lipoprotein cholesterol, $T G$ triglycerides, $C D 4^{+} T C D 4^{+} T_{-}$-cells 
and immune assessment were obtained from 51 individuals in the $\mathrm{HIV}(+)$ group and from 35 individuals in the control group. Clinical characteristics and hemodynamic values are shown in Table 1 . There were no significant group differences regarding age, TG, or LDL-c. We observed a significantly higher prevalence of smoking, greater HR $(p<0.05)$, and lower body mass index (BMI) $(p<0.05)$ in $\mathrm{HIV}(+)$. We also found a tendency for lower TC $(p=0.08)$ but significantly lower HDL-c in the $\mathrm{HIV}(+)$ group compared to HIV(-). Regarding the immunosuppression state, $65.9 \%$ of $\mathrm{HIV}(+)$ presented $\mathrm{CD}^{+}{ }^{+} \mathrm{T}$-cells count $<500$ cells $/ \mu \mathrm{L}$. We did not observe differences in peripheral (pSBP, MAP, and $\mathrm{pDBP}$ ) or cSBP between groups. In the HIV $(+)$ group, pPP showed a tendency to be lower, and cPP was significantly reduced compared to the HIV(-) group (Fig. 1). Lastly, the $\mathrm{HIV}(+)$ group exhibited greater cfPWV (mean difference $=0.5 \mathrm{~m} / \mathrm{s} ; 95 \%$ CI 0.26 to 0.86 ) compared to the uninfected group, even after adjustment for MAP, HR and current smoking (Table 2).

\section{Discussion}

We found that treatment-naïve individuals living with HIV present greater arterial stiffness compared to ageand sex-matched controls. This difference remained significant after adjusting for HR, MAP, BMI, and current smoking. Despite a greater cfPWV, we paradoxically found a tendency for lower pPP and cPP in the group living with HIV. We replicated previous findings on the harmful effect of HIV infection itself on the arterial vasculature but in a Mexican population; it is crucial to establish the effect of chronic infectious diseases in different populations such as HIV, given that the immune activation has been reported- in some studies- to vary between ethnicities [36]. For example, compared to Caucasians, Hispanic individuals have been reported to present a greater prevalence of diabetes, insulin

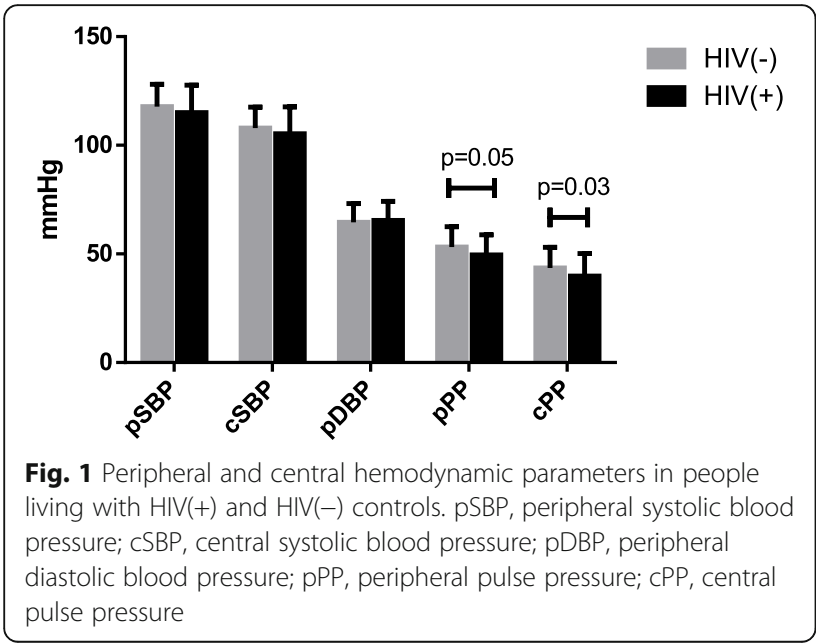

Table 2 Central hemodynamics and arterial stiffness between groups

\begin{tabular}{llll}
\hline & HIV(-) & HIV(+) & p-value \\
\hline cSBP, mmHg & $107.6 \pm 9.8$ & $105.3 \pm 12.4$ & 0.23 \\
cPP. mmHg & $42.5(36$ to 52) & $39(31$ to 47) & $\mathbf{0 . 0 3}$ \\
cfPW, $\mathrm{m} / \mathrm{s}$ & $6.7 \pm 1.0$ & $7.3 \pm 1.1$ & $\mathbf{0 . 0 4}$ \\
cfPW, $\mathrm{m} / \mathrm{s}$ (SE) & $6.8(0.12)$ & $7.4(0.12)$ & $<\mathbf{0 . 0 1}$
\end{tabular}

Values are mean \pm SD and median (IQR) unless otherwise indicated $C S B P$ central systolic blood pressure, $C P P$ central pulse pressure, cfPWV carotidfemoral pulse wave velocity

${ }^{a}$ Adjusted for MAP, HR, BMI, and current smoking. SE, standard error

resistance [37], and greater average years of life lost after HIV infection [38]. Currently, it is unknown whether Latin-American individuals living with HIV could develop, to a greater degree, metabolic abnormalities secondary to inflammation and accelerate arteriosclerosis.

\section{Arterial stiffness}

We found a greater cfPWV in treatment-naïve individuals living with HIV compared to controls, which agrees with previous reports in non-treated HIV infection [19, 39, 40]; however, others have reported similar cfPWV compared to controls [31, 41, 42]. As in our study, Schillaci et al. [43] found, besides increased cfPWV, lower BMI, and HDL-c in individuals living with HIV without ART. A greater aortic stiffness, in our studied population, could be a combination of functional and structural changes in the arterial wall. Arterial stiffness is a complex phenomenon where different factors intervene, such as endothelial dysfunction, smooth muscle vascular tone, and structural changes. One of the mechanisms that regulate endothelial function is nitric oxide $(\mathrm{NO})$. $\mathrm{NO}$ produces vasodilation, inhibits inflammation, and prevents thrombosis [44]. Chronic inflammation and greater oxidative stress impair NO by reducing its bioavailability; both processes present during HIV infection $[45,46]$. In animals, knock-out mice lacking superoxide dismutase (antioxidant) exhibited progressively greater PWV over time compared to the wild type mice [47]. In humans, a study showed that acute inflammation caused by typhoid vaccine administration resulted in endothelial dysfunction [8]. Moreover, in the early stages of HIV infection, it has been reported a decrease in glutathione [48] and total antioxidant capacity and increase in peroxidation potential [49] and gamma-glutamyl transpeptidase [18] - the latter associated with oxidative stress.

Another mechanism that may cause arterial structural changes is through matrix metalloproteinase (MMPs) dysregulation, which can which can degrade the collagen, elastin, laminin, and fibrillin within the arterial wall. Specifically, MMP-9 and MMP-2- associated with vascular remodelling [50] and increased aortic PWV [51]- have been reported to present a 3.1 
fold increase in HIV-infected macrophages and stimulated by HIV-derived proteins: envelope 120 and Tat $[52,53] \ldots$ Although these endopeptidases were not assessed in our study, this mechanism could partially explain our findings.

Some current ART regimes have shown to have negative effects on the vasculature. A prospective study by Squillace et al. [54] reported that two PI regimens (atazanavir/ritonavir and lopinavir/ritonavir) increased pro-atherosclerotic chemokines, lymphocyte adhesion molecules and no improvement in arterial function after a 6-18 month follow-up.. On the other hand, the degree of immunosuppression has been associated with carotid arterial stiffness [55]. In our HIV cohort, we observed that $63.6 \%$ of individuals had a CD4 ${ }^{+} \mathrm{T}$-cells count $<500$ cells $/ \mu \mathrm{L}$, which may indirectly indicate a long-standing HIV infection before diagnosis; thus, a chronic and more detrimental effect on the vasculature.

\section{Central hemodynamics}

We found similar brachial and central BP between groups but lower $\mathrm{cPP}$ and a tendency to decreased $\mathrm{pPP}$ in the individuals living with HIV) group compared to the HIV(-) group. The lower central and brachial PP may be caused by a combination of a slightly reduced cSBP and pSBP and higher pDBP. A slight decrease in cSBP, despite greater PWV, could be explained by peripheral vasodilation (small and medium-sized arteries), possibly due to the vasodilating effect of prostaglandins $[56,57]$ and inflammatory cytokines (i.e., interleukin 1beta) [58], through NO-independent mechanisms [59]. The vasodilation effect on peripheral reflection sites (e.g., arterial bifurcations) might cause a decreased reflection of the backward wave and a reduced contribution to cSBP [60]. Maloberti et al. [17] reported similar cPP between controls and individuals living with HIV receiving ART or naïve to it, except for those with chronic kidney disease; however, their cPP subgroup comparison was relatively small Likewise, Vlachopoulos et al. [41] reported similar cPP and cfPWV; however, they did observe a reduced cSBP in treatment-naïve $\mathrm{HIV}(+)$ compared to uninfected individuals.

\section{Lipid metabolism}

Abnormal lipid metabolism after HIV infection is common and can be caused by the HIV infection itself, chronic inflammation, and ART (i.e., PI) [61, 62], which could lead to the development of metabolic syndrome (MetS). MetS is more prevalent in people living with HIV compared to non-infected, and further aggravated after ART [63]. Maloberti et al. [63] reported a higher prevalence of MetS in individuals with HIV receiving ART (19.4\%) and treatment-naïve HIV individuals (13.8\%) compared to controls (4.5\%). In our study, we found a tendency for lower TC, significantly lower HDLc, and similar TG levels in treatment-naïve HIV compared to uninfected controls. The majority of the individuals living with HIV in our study presented HDLc $<1.04 \mathrm{mmol} / \mathrm{L}(78.2 \%$ vs. $21.8 \%)$ and TC $<5.2 \mathrm{mmol} / \mathrm{L}$ (60.8\% vs. 39.2\%) compared to the HIV(-) group, respectively [6]. Arterial stiffness has been associated with dyslipidaemia [64], in particular, hypertriglyceridemia and HDL-c play an essential role in the development of CVD. HDL-c provides atherogenic protection, prevents vascular inflammation [65] and oxidative stress [66]; thus, preserving endothelial function $[67,68]$.

Previous findings of the effect of HIV on arterial stiffness have not been consistent. This can be due to several causes, including a pooled comparison of individuals receiving and not receiving ART and different methodologies to assess arterial stiffness such as brachial-ankle PWV [69] and one-point PWV [70]. By exploring treatment-naïve individuals living with HIV, this study allowed us to exclude the potential negative effect of ART on the arterial system and evaluate the impact of HIV infection and traditional risk factors.

Our study has some limitations. Due to its crosssectional design, we were unable to establish a causal relationship. The smoking history was statistically adjusted and we were not able to assess the presence of MetS due to the absence of basal waist measurements. In addition, factors such as unemployment, education, and socioeconomic status have been associated with arterial health, and where not measured in our study participants. Future studies should evaluate the behaviour of biomarkers of inflammation or vascular disease in response to different ART combinations to better understand their effects on the vasculature.

\section{Conclusion}

Our study provides evidence that, in the early stages, non-treated HIV individuals living with HIV present greater arterial stiffness and prevalence of traditional CVD risk factors compared to non-infected controls. Paradoxically, central hemodynamics appears to remain unchanged or present a favourable profile.

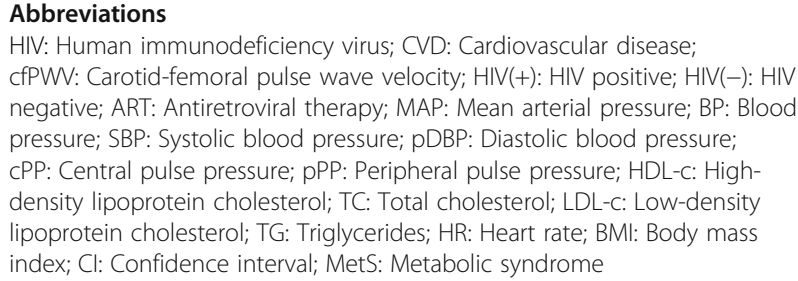

\section{Acknowledgments}

We would like to thank Raul Soria-Rodríguez, Ruth Lisbeth Ibarra-Jiménez, and the personnel of the HIV Unit Department, University Hospital "Fray Antonio Alcalde" for their invaluable help with sample processing. 


\section{Authors' contributions}

PM-A, GAA-S, CR-B, DC-M, LAG-H, JFA-V, ST-S, and EGC-M conceptualized and designed the study methodology. DAC-Z, CR-B, and GAA-S performed the vascular assessments. GAA-S, RIC-S, KS-R, MA-Z, MR-S, and DAC-Z performed data curation and formal analysis was conducted by GAA-S, PM-A, CR-B, and RIC-S. GAA-S and PM-A drafted the original manuscript. PM-A, RICS, KS-R, MA-Z, LAG-H, EGC-M, JFA-V reviewed and edited the manuscript. The author(s) read and approved the final manuscript.

\section{Funding}

The authors received no financial support to conduct this study.

\section{Availability of data and materials}

The datasets used or analyzed during the current study are available from the corresponding author on reasonable request.

\section{Ethics approval and consent to participate}

The University of Guadalajara ethics committee approved the study and full informed written consent was obtained from all participants. Approval number 208/15

\section{Consent for publication}

Not applicable.

\section{Competing interests}

The authors declare that they have no competing interests.

\section{Author details}

"HIV Unit Department, University Hospital "Fray Antonio Alcalde", Universidad de Guadalajara, Guadalajara, Mexico. ${ }^{2}$ Arterial Stiffness Laboratory, Department of Physiology, Universidad de Guadalajara, Sierra Mojada 950, Building Q, Ground Floor, District Independencia, 44340 Guadalajara, Jalisco, Mexico. ${ }^{3} \mathrm{HIV}$ and Immunodeficiencies Research Institute, Clinical Medicine Department, CUCS-Universidad de Guadalajara, Guadalajara, Mexico.

\section{Received: 8 April 2020 Accepted: 1 October 2020}

\section{Published online: 07 October 2020}

\section{References}

1. Triant VA, Lee H, Hadigan C, Grinspoon SK. Increased acute myocardial infarction rates and cardiovascular risk factors among patients with human immunodeficiency virus disease. J Clin Endocrinol Metab. 2007; 92(7):2506-12

2. Chow FC, Regan S, Feske S, Meigs JB, Grinspoon SK, Triant VA. Comparison of ischemic stroke incidence in HIV-infected and non-HIV-infected patients in a US health care system. J Acquir Immune Defic Syndr. 2012;60(4):351-8.

3. Butt AA, Chang C-C, Kuller L, Goetz MB, Leaf D, Rimland D, Gibert CL, Oursler KK, Rodriguez-Barradas MC, Lim J. Risk of heart failure with human immunodeficiency virus in the absence of prior diagnosis of coronary heart disease. Arch Intern Med. 2011;171(8):737-43.

4. Stacey AR, Norris PJ, Qin L, Haygreen EA, Taylor E, Heitman J, Lebedeva M, DeCamp A, Li D, Grove D. Induction of a striking systemic cytokine cascade prior to peak viremia in acute human immunodeficiency virus type 1 infection, in contrast to more modest and delayed responses in acute hepatitis B and C virus infections. J Virol. 2009;83(8):3719-33.

5. Vazquez-Castellanos J, Serrano-Villar S, Latorre A, Artacho A, Ferrus M, Madrid N, Vallejo A, Sainz T, Martínez-Botas J, Ferrando-Martínez S. Altered metabolism of gut microbiota contributes to chronic immune activation in HIV-infected individuals. Mucosal Immunol. 2015;8(4):760-72.

6. Daniyam C, Iroezindu M. Lipid profile of anti retroviral treatment naive HIV infected patients in Jos, Nigeria. Ann Med Health Sci Res. 2013;3(1):26-30.

7. Grunfeld C, Pang M, Doerrler W, Shigenaga JK, Jensen P, Feingold KR. Lipids, lipoproteins, triglyceride clearance, and cytokines in human immunodeficiency virus infection and the acquired immunodeficiency syndrome. J Clin Endocrinol Metab. 1992;74(5):1045-52.

8. Clapp BR, Hingorani AD, Kharbanda RK, Mohamed-Ali V, Stephens JW, Vallance P, MacAllister RJ. Inflammation-induced endothelial dysfunction involves reduced nitric oxide bioavailability and increased oxidant stress. Cardiovasc Res. 2004;64(1):172-8.
9. Dubé MP, Gorski JC, Shen C. Severe impairment of endothelial function with the HIV-1 protease inhibitor indinavir is not mediated by insulin resistance in healthy subjects. Cardiovasc Toxicol. 2008;8(1):15-22.

10. Gujuluva C, Burns AR, Pushkarsky T, Popik W, Berger O, Bukrinsky M, Graves MC, Fiala M. HIV-1 penetrates coronary artery endothelial cells by transcytosis. Mol Med. 2001;7(3):169-76.

11. Toborek M, Lee YW, Pu H, Malecki A, Flora G, Garrido R, Hennig B, Bauer HC, Nath A. HIV-tat protein induces oxidative and inflammatory pathways in brain endothelium. J Neurochem. 2003;84(1):169-79.

12. Yarasheski KE, Laciny E, Overton ET, Reeds DN, Harrod M, Baldwin S, DávilaRomán VG. 18 FDG PET-CT imaging detects arterial inflammation and early atherosclerosis in HIV-infected adults with cardiovascular disease risk factors. J Inflamm. 2012;9(1):26.

13. Prskalo Z, Brizić I, Markota D, Markota I, Boban M, Tomic M, Starcevic B. Arterial stiffness in patients with coronary artery disease: relation with instent restenosis following percutaneous coronary intervention. BMC Cardiovasc Disord. 2016;16(1):128

14. Weber T, Auer J, O'Rourke MF, Kvas E, Lassnig E, Berent R, Eber B. Arterial stiffness, wave reflections, and the risk of coronary artery disease. Circulation. 2004;109(2):184-9.

15. Mattace-Raso FU, van der Cammen TJ, Hofman A, van Popele NM, Bos ML, Schalekamp M, Asmar R, Reneman RS, Hoeks AP, Breteler MM. Arterial stiffness and risk of coronary heart disease and stroke. Circulation. 2006; 113(5):657-63.

16. Gleason RL Jr, Caulk AW, Seifu D, Parker I, Vidakovic B, Getenet H, Assefa G, Amogne W. Current Efavirenz (EFV) or ritonavir-boosted lopinavir (LPV/r) use correlates with elevate markers of atherosclerosis in HIV-infected subjects in Addis Ababa, Ethiopia. PLoS One. 2015;10(4):e0117125.

17. Maloberti A, Dozio D, Betelli M, Bandera A, Squillace N, Gori A, Castoldi G, Stella A, Mancia G, Giannattasio C. Brachial and central blood pressure in HIV-infected subjects. Hypertens Res. 2015;38(6):405.

18. Schillaci G, De Socio GV, Pucci G, Mannarino MR, Helou J, Pirro M, Mannarino E. Aortic stiffness in untreated adult patients with human immunodeficiency virus infection. Hypertension. 2008;52(2):308-13.

19. Lekakis J, Ikonomidis I, Palios J, Tsiodras S, Karatzis E, Poulakou G, Rallidis L, Antoniadou A, Panagopoulos P, Papadopoulos A. Association of highly active antiretroviral therapy with increased arterial stiffness in patients infected with human immunodeficiency virus. Am J Hypertens. 2009;22(8):828-34

20. Safar ME, Henry O, Meaume S. Aortic pulse wave velocity: an independent marker of cardiovascular risk. Am J Geriatr Cardiol. 2002;11(5):295-304.

21. Shokawa T, Imazu M, Yamamoto H, Toyofuku M, Tasaki N, Okimoto T, Yamane K, Kohno N. Pulse wave velocity predicts cardiovascular mortality. Circ J. 2005:69(3):259-64.

22. Meaume S, Benetos A, Henry O, Rudnichi A, Safar M. Aortic pulse wave velocity predicts cardiovascular mortality in subjects $>70$ years of age. Arterioscler Thromb Vasc Biol. 2001;21(12):2046-50.

23. Kollias A, Lagou S, Zeniodi ME, Boubouchairopoulou N, Stergiou GS. Association of Central Versus Brachial Blood Pressure with Target-Organ Damage: systematic review and meta-analysis. Hypertension. 2016;67(1): 183-90.

24. Safar ME, Blacher J, Pannier B, Guerin AP, Marchais SJ, Guyonvarc'h P-M, London GM. Central pulse pressure and mortality in end-stage renal disease. Hypertension. 2002;39(3):735-8.

25. Roman MJ, Devereux RB, Kizer JR, Lee ET, Galloway JM, Ali T, Umans JG, Howard BV. Central pressure more strongly relates to vascular disease and outcome than does brachial pressure: the strong heart study. Hypertension. 2007;50(1):197-203.

26. $\mathrm{Xu} Y$, Chen $X$, Wang $\mathrm{K}$. Global prevalence of hypertension among people living with HIV: a systematic review and meta-analysis. J Am Soc Hypertens. 2017;11(8):530-40.

27. Freiberg MS, Chang CC, Kuller LH, Skanderson M, Lowy E, Kraemer KL, Butt AA, Bidwell Goetz M, Leaf D, Oursler KA, et al. HIV infection and the risk of acute myocardial infarction. JAMA Intern Med. 2013;173(8):614-22.

28. Lopez-Sublet M, Honoré P, Bentata M, Bratis $C$, Rouges F, Krivitzky A, Dhôte $R$, Mourad JJ. Protease inhibitor treatment effect on aortic stiffness in normotensive patients with human immunodeficiency virus infection. J Mal Vasc. 2012;37(4):179-85.

29. Monteiro P, Miranda-Filho D, Bandeira F, Lacerda H, Chaves H, Albuquerque $M$, Montarroyos $U$, Ximenes R. Is arterial stiffness in HIV-infected individuals associated with HIV-related factors? Braz J Med Biol Res. 2012;45(9):818-26. 
30. Echeverría P, Bonjoch A, Moltó J, Jou A, Puig J, Ornelas A, Pérez-Álvarez N, Clotet B, Negredo E. Pulse wave velocity as index of arterial stiffness in HIVinfected patients compared with a healthy population. J Acquir Immune Defic Syndr. 2014;65(1):50-6.

31. Eira M, Bensenor IM, Dorea EL, Cunha RS, Mill JG, Lotufo PA. Potent antiretroviral therapy for human immunodeficiency virus infection increases aortic stiffness. Arq Bras Cardiol. 2012;99(6):1100-7.

32. Laurent S, Cockcroft J, Van Bortel L, Boutouyrie P, Giannattasio C, Hayoz D, Pannier B, Vlachopoulos C, Wilkinson I, Struijker-Boudier H. Expert consensus document on arterial stiffness: methodological issues and clinical applications. Eur Heart J. 2006;27(21):2588-605.

33. Townsend RR, Wilkinson IB, Schiffrin EL, Avolio AP, Chirinos JA, Cockcroft JR, Heffernan KS, Lakatta EG, McEniery CM, Mitchell GF. Recommendations for improving and standardizing vascular research on arterial stiffness: a scientific statement from the American Heart Association. Hypertension. 2015;66(3):698-722.

34. Determinants of pulse wave velocity in healthy people and in the presence of cardiovascular risk factors: 'establishing normal and reference values'. Eur Heart J. 2010:31(19):2338-50.

35. Faul F, Erdfelder E, Lang AG, Buchner A. G* power 3: a flexible statistical power analysis program for the social, behavioral, and biomedical sciences. Behav Res Methods. 2007;39(2):175-91.

36. Haralambieva IH, Ovsyannikova IG, Kennedy RB, Larrabee BR, Pankratz VS, Poland GA. Race and sex-based differences in cytokine immune responses to smallpox vaccine in healthy individuals. Hum Immunol. 2013;74(10):1263-6.

37. Haffner SM, Saad MF, Rewers M, Mykkänen L, Selby J, Howard G, Savage PJ, Hamman RF, Wegenknecht LE, Bergman RN. Increased insulin resistance and insulin secretion in nondiabetic African-Americans and Hispanics compared with non-Hispanic whites: the insulin resistance atherosclerosis study. Diabetes. 1996:45(6):742-8.

38. Harrison KM, Song R, Zhang X. Life expectancy after HIV diagnosis based on national HIV surveillance data from 25 states, United States. J Acquir Immune Defic Syndr. 2010;53(1):124-30.

39. Rose H, Low H, Dewar E, Bukrinsky M, Hoy J, Dart A, Sviridov D. The effect of HIV infection on atherosclerosis and lipoprotein metabolism: a one year prospective study. Atherosclerosis. 2013;229(1):206-11.

40. Baker JV, Duprez D, Rapkin J, Hullsiek KH, Quick H, Grimm R, Neaton JD, Henry K. Untreated HIV infection and large and small artery elasticity. J Acquir Immune Defic Syndr. 2009;52(1):25.

41. Vlachopoulos C, Sambatakou H, Tsiachris D, Mariolis I, Aznaouridis K, loakeimidis N, Archimandritis AJ, Stefanadis C. Impact of human immunodeficiency virus infection on arterial stiffness and wave reflections in the early disease stages. Artery Res. 2009;3(3):104-10.

42. van Vonderen MG, Hassink EA, van Agtmael MA, Stehouwer CD, Danner SA, Reiss $P$, Smulders $Y$. Increase in carotid artery intima-media thickness and arterial stiffness but improvement in several markers of endothelial function after initiation of antiretroviral therapy. J Infect Dis. 2009;199(8):1186-94

43. Schillaci G, De Socio GV, Pirro M, Savarese G, Mannarino MR, Baldelli F, Stagni G, Mannarino E. Impact of treatment with protease inhibitors on aortic stiffness in adult patients with human immunodeficiency virus infection. Arterioscler Thromb Vasc Biol. 2005;25(11):2381-5.

44. Gutterman DD, Chabowski DS, Kadlec AO, Durand MJ, Freed JK, Ait-Aissa K, Beyer AM. The human microcirculation: regulation of flow and beyond. Circ Res. 2016;118(1):157-72.

45. Deeks SG, Tracy R, Douek DC. Systemic effects of inflammation on health during chronic HIV infection. Immunity. 2013;39(4):633-45.

46. Ivanov AV, Valuev-Elliston VT, Ivanova ON, Kochetkov SN, Starodubova ES, Bartosch B, Isaguliants MG. Oxidative stress during HIV infection: mechanisms and consequences. Oxidative Med Cell Longev. 2016;2016: 8910396.

47. Zhou R-H, Vendrov AE, Tchivilev I, Niu X-L, Molnar KC, Rojas M, Carter JD, Tong $H$, Stouffer GA, Madamanchi NR. Mitochondrial oxidative stress in aortic stiffening with age: the role of smooth muscle cell function. Arterioscler Thromb Vasc Biol. 2012;32(3):745-55.

48. Bogden JD, Kemp FW, Han S, Li W, Bruening K, Denny T, Oleske JM, Lloyd J, Baker H, Perez G. Status of selected nutrients and progression of human immunodeficiency virus type 1 infection. Am J Clin Nutr. 2000;72(3):809-15.

49. Gil L, Martínez G, González I, Tarinas A, Álvarez A, Giuliani A, Molina R, Tápanes R, Pérez J, León OS. Contribution to characterization of oxidative stress in HIV/AIDS patients. Pharmacol Res. 2003;47(3):217-24.
50. Godin D, Ivan E, Johnson C, Magid R, Galis ZS. Remodeling of carotid artery is associated with increased expression of matrix metalloproteinases in mouse blood flow cessation model. Circulation. 2000;102(23):2861-6.

51. Yasmin WS, McEniery CM, Dakham Z, Pusalkar P, Maki-Petaja K, Ashby MJ, Cockcroft JR, Wilkinson IB. Matrix metalloproteinase-9 (MMP-9), MMP-2, and serum elastase activity are associated with systolic hypertension and arterial stiffness. Arterioscler Thromb Vasc Biol. 2005;25(2):372-8.

52. Misse D, Esteve P-O, Renneboog B, Vidal M, Cerutti M, St Pierre Y, Yssel H, Parmentier M, Veas F. HIV-1 glycoprotein 120 induces the MMP-9 cytopathogenic factor production that is abolished by inhibition of the p38 mitogen-activated protein kinase signaling pathway. Blood. 2001; 98(3):541-7

53. Ju SM, Song HY, Lee JA, Lee SJ, Choi SY, Park J. Extracellular HIV-1 tat upregulates expression of matrix metalloproteinase-9 via a MAPK-NF-KB dependent pathway in human astrocytes. Exp Mol Med. 2009;41(2):86-93.

54. Squillace $N$, Trabattoni D, Muscatello A, Sabbatini F, Maloberti A, Giannattasio C, Masetti M, Fenizia C, Soria A, Clerici M, et al. Evaluation of adhesion molecules and immune parameters in HIV-infected patients treated with an atazanavir/ritonavir- compared with a lopinavir/ritonavirbased regimen. J Antimicrob Chemother. 2018;73(8):2162-70.

55. Seaberg EC, Benning L, Sharrett AR, Lazar JM, Hodis HN, Mack WJ, Siedner MJ, Phair JP, Kingsley LA, Kaplan RC. Association between human immunodeficiency virus infection and stiffness of the common carotid artery. Stroke. 2010;41(10):2163-70.

56. Delemarre F, Stevenhagen A, Kroon FP, Meenhorst P. Reduced toxoplasmastatic activity of monocytes and monocyte-derived macrophages from AIDS patients is mediated via prostaglandin E2. AIDS 1995;9(5):441-5.

57. Foley P, Kazazi F, Biti R, Sorrell TC, Cunningham AL. HIV infection of monocytes inhibits the T-lymphocyte proliferative response to recal antigens, via production of eicosanoids. Immunology. 1992;75(3):391-7.

58. Weiss L, Haeffner-Cavaillon N, Laude M, Gilquin J, Kazatchkine MD. HIV infection is associated with the spontaneous production of interleukin-1 (IL1) in vivo and with an abnormal release of IL-1 alpha in vitro. AIDS (London, England). 1989;3(11):695-9.

59. Ricciotti E, FitzGerald GA. Prostaglandins and inflammation. Arterioscler Thromb Vasc Biol. 2011;31(5):986-1000.

60. O'Rourke M. Systolic blood pressure: arterial compliance and early wave reflection, and their modification by antihypertensive therapy. J Hum Hypertens. 1989;3(Suppl 1):47-52.

61. Fellay J, Ledergerber B, Bernasconi E, Furrer H, Battegay M, Hirschel B, Vernazza P, Francioli P, Greub G, Flepp M. Prevalence of adverse events associated with potent antiretroviral treatment: Swiss HIV cohort study. Lancet. 2001;358(9290):1322-7.

62. Dubé MP, Sprecher D, Henry WK, Aberg JA, Torriani FJ, Hodis HN, Schouten J, Levin J, Myers G, Zackin R, et al. Preliminary guidelines for the evaluation and management of dyslipidemia in adults infected with human immunodeficiency virus and receiving antiretroviral therapy: recommendations of the adult AIDS clinical trial group cardiovascular disease focus group. Clin Infect Dis. 2000;31(5):1216-24.

63. Maloberti A, Giannattasio C, Dozio D, Betelli M, Villa P, Nava S, Cesana F, Facchetti R, Giupponi L, Castagna F, et al. Metabolic syndrome in human immunodeficiency virus-positive subjects: prevalence, phenotype, and related alterations in arterial structure and function. Metab Syndr Relat Disord. 2013;11(6):403-11.

64. Lopes-Vicente WRP, Rodrigues S, Cepeda FX, Jordão CP, Costa-Hong V, Dutra-Marques ACB, Carvalho JC, Alves M, Bortolotto LA, Trombetta IC. Arterial stiffness and its association with clustering of metabolic syndrome risk factors. Diabetol Metab Syndr. 2017;9:87.

65. Cockerill GW, Huehns TY, Weerasinghe A, Stocker C, Lerch PG, Miller NE, Haskard DO. Elevation of plasma high-density lipoprotein concentration reduces interleukin-1-induced expression of E-selectin in an in vivo model of acute inflammation. Circulation. 2001;103(1):108-12.

66. Kontush A, Chapman MJ. Antiatherogenic function of HDL particle subpopulations: focus on antioxidative activities. Curr Opin Lipidol. 2010;21(4):312-8.

67. Mineo C, Shaul PW. HDL stimulation of endothelial nitric oxide synthase: a novel mechanism of HDL action. Trends Cardiovasc Med. 2003;13(6):226-31.

68. Spieker LE, Sudano I, Hürlimann D, Lerch PG, Lang MG, Binggeli C, Corti R, Ruschitzka F, Lüscher TF, Noll G. High-density lipoprotein restores endothelial function in hypercholesterolemic men. Circulation. 2002;105(12): 1399-402. 
69. Zeng Y, Ye YC, Luo L, Qiu ZF, Han Y, Li XM, Fang Q, Zhang SY, Li TS. Premature atherosclerosis in patients with acquired immunodeficiency syndrome. Chin Med J. 2010;123(23):3396-9.

70. Ferraioli G, Tinelli C, Maggi P, Gervasoni C, Grima P, Viskovic K, Carerj S, Filice G, Filice C. Group ASEiH-ISS: arterial stiffness evaluation in HIV-positive patients: a multicenter matched control study. AJR Am J Roentgenol. 2011; 197(5):1258-62.

\section{Publisher's Note}

Springer Nature remains neutral with regard to jurisdictional claims in published maps and institutional affiliations.

Ready to submit your research? Choose BMC and benefit from:

- fast, convenient online submission

- thorough peer review by experienced researchers in your field

- rapid publication on acceptance

- support for research data, including large and complex data types

- gold Open Access which fosters wider collaboration and increased citations

- maximum visibility for your research: over $100 \mathrm{M}$ website views per year

At BMC, research is always in progress.

Learn more biomedcentral.com/submissions 